\title{
The impact of ancestral heath management on soils and landscapes: a reconstruction based on paleoecological analyses of soil records in the central and southeastern Netherlands
}

\author{
Marieke Doorenbosch $^{1}$ and Jan M. van Mourik ${ }^{2}$ \\ ${ }^{1}$ Faculty of Archaeology, University of Leiden, Einsteinweg 2, 2333CC Leiden, the Netherlands \\ ${ }^{2}$ Institute for Biodiversity and Ecosystem Dynamics, University of Amsterdam, Science Park 904, \\ 1098 XH Amsterdam, the Netherlands \\ Correspondence to: Marieke Doorenbosch (m.doorenbosch@arch.leidenuniv.nl) \\ Received: 14 November 2015 - Published in SOIL Discuss.: 18 January 2016 \\ Revised: 25 May 2016 - Accepted: 27 May 2016 - Published: 4 July 2016
}

\begin{abstract}
The evolution of heathlands during the Holocene has been registered in various soil records. Paleoecological analyses of these records enable reconstruction of the changing economic and cultural management of heaths and the consequences for landscape and soils.

Heaths are characteristic components of cultural landscape mosaics on sandy soils in the Netherlands. The natural habitat of heather species was moorland. At first, natural events like forest fires and storms caused smallscale forest degradation; in addition on that, the forest degradation accelerated due to cultural activities like forest grazing, wood cutting, and shifting cultivation. Heather plants invaded degraded forest soils, and heaths developed. People learned to use the heaths for economic and cultural purposes. The impact of the heath management on landscape and soils was registered in soil records of barrows, drift sand sequences, and plaggic Anthrosols. Based on pollen diagrams of such records we could reconstruct that heaths were developed and used for cattle grazing before the Bronze Age. During the late Neolithic, the Bronze Age, and Iron Age, people created the barrow landscape on the ancestral heaths. After the Iron Age, people probably continued with cattle grazing on the heaths and plaggic agriculture until the early Middle Ages. Severe forest degradation by the production of charcoal for melting iron during the Iron Age till the 6th-7th century and during the 11th-13th century for the trade of wood resulted in extensive sand drifting, a threat to the valuable heaths. The introduction of the deep, stable economy and heath sods digging in the course of the 18th century resulted in acceleration of the rise of plaggic horizons, severe heath degradation, and again extension of sand drifting. At the end of the 19th century heath lost its economic value due to the introduction of chemical fertilizers. The heaths were transformed into "new" arable fields and forests, and due to deep ploughing most soil archives were destroyed. Since AD 1980, the remaining relicts of the ancestral heaths are preserved and restored in the frame of the programs to improve the regional and national geo-biodiversity. Despite the realization of many heath restoration projects during the last decades, the area of the present heaths is just a fraction of the heath areal in AD 1900.
\end{abstract}




\section{Introduction}

Heaths are characteristic biotopes in northwestern Europe. Most of the heaths in the study area occur on Late Glacial cover sand and Holocene drift sand deposits. The current biodiversity management regards dry and moist heaths as region-specific ecotopes that need to be preserved and protected (LNV, 2001, 2006). Erica tetralix dominated the moist heaths, and Calluna vulgaris the dry heaths; both species grow on acidic, humic soils, poor in nitrogen and phosphate (Weeda et al., 1988; LNV, 2001). Originally, the term heath was not connected to a vegetation type but to common fields for cattle grazing on chemically poor sandy soils. The family of Ericaceae encompasses $\approx 3000$ cosmopolitan ligneous plant species, of which seven occur in the Netherlands.

Two factors are crucial for the survival of heaths on chemical poor sandy substrates (Weeda et al., 1988).

1. Heath plants live in symbiosis with ericoid mycorrhiza. These organisms provide the heath plants with nitrogen that is hardly available for other plants, which live without this form of symbiosis.

2. Heath plants have specific adaptations to drought stress. Leaves will stop evaporation of water under dry or warm air conditions but can evaporate large amounts of water under humid air conditions. These adaptations enable heath plants to enhance nutrient uptake from soil water with low nutrient concentrations. In this way heath plants are able to concentrate the sufficient amount of nutrients necessary for plant growth from soil water that contains low nutrient concentrations.

Moors on poorly drained soils formed the natural habitats for heath plants. Erica tetralix dominated in the lower parts of the moors, and Calluna vulgaris on the drier rises of Sphagnum peat (Weeda et al., 1988). The occurrence of Ericaceae in the cover sand landscape was reported in pollen diagrams of initial Histosols, developed during the Bølling and Allerød interstadials (van Geel et al., 1989; van Mourik and Slotboom, 1995). The Holocene migration of heath species from the moors to the cover sand landscapes was initially triggered by environmental events such as storm and forest fires and then accelerated by cultural factors such as deforestation and agriculture.

The Holocene vegetation development and soil formation on cover sands started without significant human interference. At that time, the soilscape was in accordance with the geomorphological structure: xeromorphic podzols on cover sand ridges, gleyic podzols on cover sand planes, and histic podzols in brook valleys. During the early Holocene, natural events such as forest fires and storms caused small-scale forest degradation and created habitats outside the bogs where heath could develop. It was long thought that this situation continued until the late Neolithic, but now there are reasons to believe that the activities of pre-agricultural communi- ties from before $\approx 5000 \mathrm{BC}$ already had significant impact on the landscape. This is shown by Sevink et al. (2013) in the Laarderwasmeer area. Sevink et al. (2013) have studied several paleosols in which very early periods of sand drifting events were recorded, with optically stimulated luminescence (OSL) dated to 8800-6500, 6400-5800, and 53004800 years BP. Pollen analyses showed that heath was dominating the vegetation already before the earliest recorded sand drifting period. Sevink et al. (2013) concluded that, although there are no indications of farming or intensive grazing in that period, the most likely explanation for the early heath dominance associated with sand drifting was the activity of the population living in the area, since they cannot be linked to climatic changes and the youngest sand drifting period in the Laarderwasmeer area coincides with the start of the barrow building in the area, indicating increasing intensity of the use of the area by prehistoric man. This was also suggested by Willemse and Groenewoudt (2012), who considered early Neolithic sand drifting periods in the Dutch river valleys to be of human origin.

Several other comprehensive studies, based on soil archives, have been performed to explore the causes of Holocene sand drifting in the areas Drenthe (Riksen et al., 2006; Castel, 1991), Veluwe (Koster, 1978), and the SE Netherlands (van Mourik et al., 2012a, b). In the pollen diagrams presented in these studies, Calluna plays a significant role, but hardly any attention was paid to the role of (pre)historical heath management.

From the late Neolithic onwards, the effect of human land use on soil and landscape increased. The deciduous forest gradually degraded by some woodcutting, forest grazing, and shifting cultivation (van Mourik et al., 2012a, b), and the heaths that were already present in the area could expand. Most probably, the valuable common heaths on aeolian sandy soils were sustainably managed by the community (de Keyzer, 2014). However, periods of severe forest degradation and sand drifting threatened the survival of the heaths. Since the early Iron Age, forest degradation was triggered by the use of oak trees for the production of charcoal to melt iron from bog iron ore, rattle stones, and plaggic horizons (Laban et al., 1988). The production of iron resulted in extensive sand drifting in the Veluwe region from the Iron Age until the 6th-7th century (Beukenkamp and Sevink, 2005). During the 11th-13th century the clear cutting of forests for the sale of wood resulted in extensive sand drifting in the SE Netherlands (van Mourik et al., 2012a, b; Vera, 2011). In the course of the 18th century, the deep, stable economy and digging of heath sods were introduced. On the one hand, this accelerated the rise of plaggic horizons; on the other hand, heaths degraded severely and sand drifting extended again.

Nowadays, many moist and dry heath areas in the Netherlands are protected, as they form part of national and (pan)European ecological networks (LNV, 2001, 2006; Jongman et al., 2011). In order to preserve the heath areas, future sus- 


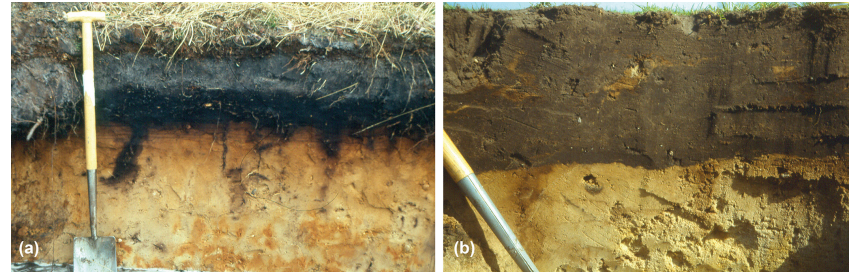

Figure 1. Destruction of soil archives on the Maashorst (North Brabant) during the transition of (former) heaths into modern arable fields. Left: undisturbed gleyic podzol; right: deeply ploughed podzol.

tainable heath management must be based on knowledge on the origin of heath biotopes and the role of heaths in historical land use systems (Smits and Noordijk, 2013).

Information about historical land management on cover sands can be unlocked from soil archives. In the course of the 20th century, the majority of the heaths were transformed into arable land and forest plantations. Soils were deeply ploughed, and soil archives were severely damaged or even destroyed (Fig. 1).

As a consequence the total heath area in the Netherlands decreased from 600000 to 30000 ha (Fig. 2). Remaining parts of eligible soil archives can be found as paleosols underneath barrows, i.e., burial mounds (Doorenbosch, 2013), polycyclic sequences in drift sand landscapes (van Mourik et al., 2012a, b; Sevink et al., 2013), and plaggic Anthrosols (Spek, 2004; van Mourik et al., 2011). Some of these archives have now been included in managed nature reserves and are considered as cultural heritage.

The aim of this paper is to reconstruct the impact of ancestral heath management on the development of soils (podzols, Arenosols, and plaggic Anthrosols) and landforms (barrows, drift sand covers, and dunes) based on previously published research cases. Key sites that were used for this paper include recently investigated barrow paleosols (Doorenbosch, 2013) and a cross section through an inland dune ridge (van Mourik et al., 2012a). These sites will be described and discussed in detail in the following sections. The soil records from the barrow landscapes cover the period between $\approx 3000 \mathrm{BC}$ and the Roman period. The soil archives from the cross section of the dune ridge cover the period after the Roman period and 1900. Little information is available in the literature about heath management from the beginning of the Roman period until the early Middle Ages. However, the continuity of the Ericaceae in pollen diagrams of raised bogs and paleosols suggests the continuity of heaths during this period, probably as extensive grazing areas, without clear registration in the soil archives.

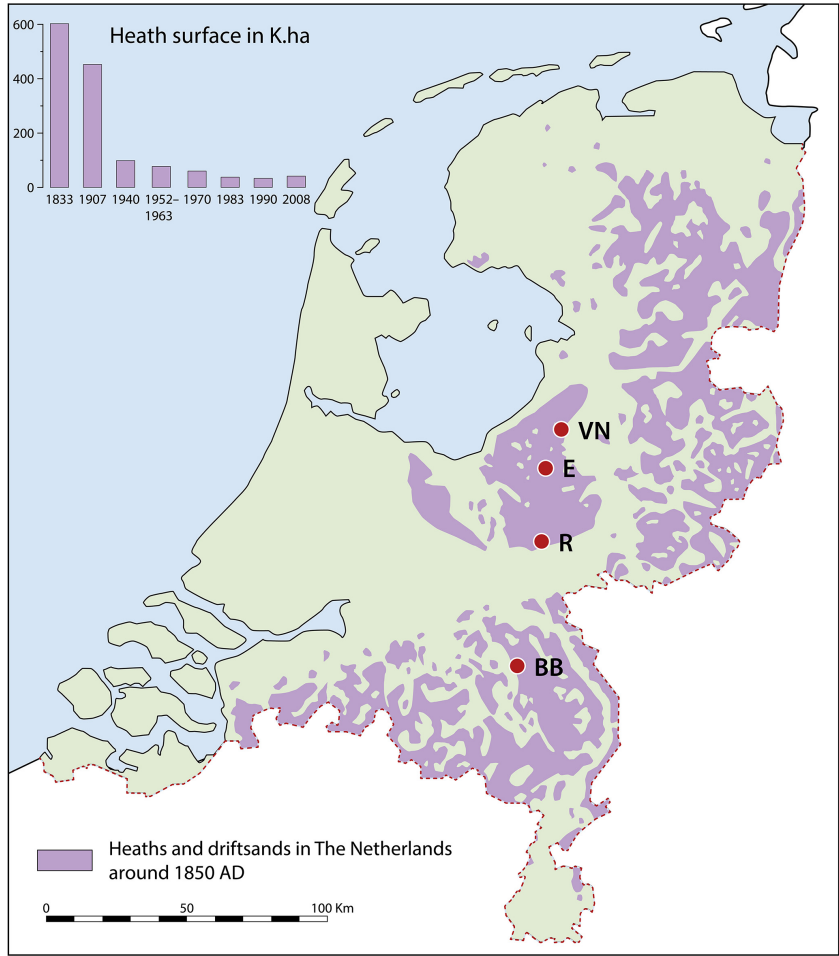

Figure 2. Heath area in the Netherlands around AD 1850 and the diminution of heaths between 1833 and 2008. The locations of the four research sites are indicated: VN - Vaassen-Niersen; R Renkum stream valley; E - Echoput; BB - Bedafse Bergen.

\section{Materials and methods}

\subsection{Profile selection}

Barrows, mounds underneath or in which prehistoric humans buried the dead, were built from $\approx 3000 \mathrm{BC}$ (the late $\mathrm{Ne}$ olithic period) until $\approx 100 \mathrm{BC}$ (the late Iron Age). Around 4000 barrows are known to be still present in the Netherlands, but, considering the large amount of barrows that has disappeared over time, there must have been thousands of burial mounds in the Netherlands, dominating the morphology of the sandy Pleistocene landscape.

Many of these burial mounds have been excavated and sampled for pollen analysis to reconstruct the barrow environment (Fig. 3). To reconstruct environmental development, pollen spectra of samples from the mounds are less valuable, but spectra of samples of the buried podzols underneath a barrow, with the pre-barrow land surface on top, are opportune with the restriction of the regular complications of soil pollen spectra (van Mourik, 2001). Pollen grains precipitate onto the land surface and infiltrate by bioturbation into the soil profile and reach the A, E, B, and even the $\mathrm{C}$ horizons. Soil acidification, a regular development during the Holocene in sandy substrates, caused retrogressive activity during acidic soil formation. Hence, older pollen as- 


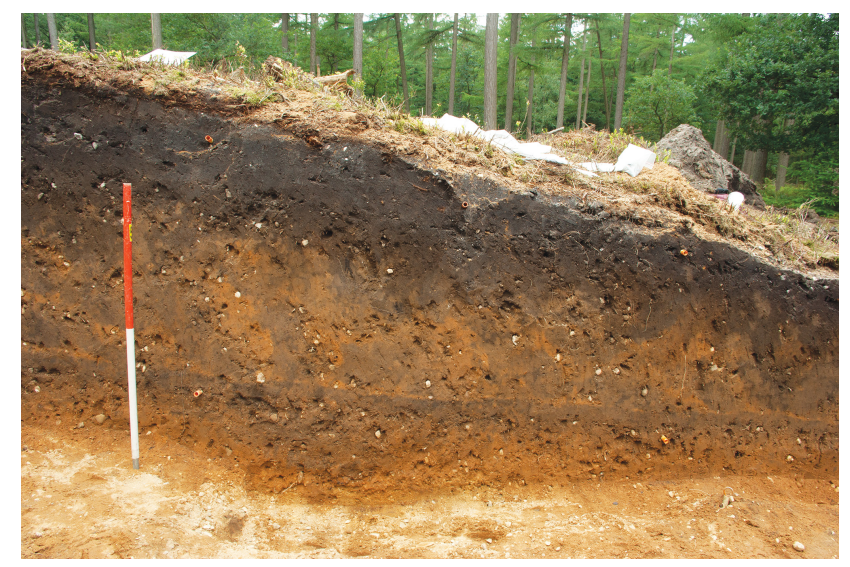

Figure 3. Soil record of a barrow showing a paleosol buried by a barrow, built with sods, dug in heathlands in the surroundings. Photograph by Q. Bourgeois.

semblages will be preserved in the lower parts of the soil (van Mourik, 1999, 2001). When the soil was buried during the construction of the barrow, the active soil processes stopped and the soil record was conserved. The pollen grains incorporated into the paleosol before and during the time that barrow was built are in many cases still present today.

A barrow is usually constructed of sods. These sods were taken from the upper part of the soil in the surroundings and placed upside down when building the barrow. Sods contain parts of the soil record from the place where they were taken, including pollen grains. Pollen spectra of the constructing materials and the paleosol have been used to reconstruct the morphology of the barrow landscape (Waterbolk, 1954; Groenman-van Waateringe, 1988; Bloemers, 1988; Doorenbosch, 2013). These investigations have revealed that all studied barrows were built in heath vegetation that has been kept in existence mainly by human activities for several millennia, before, during, and after the barrows were constructed. The management of heath will be further specified in the following paragraphs of this article.

For this paper we used the cases of the Renkum stream valley, Vaassen-Niersen, and Echoput, previously published in Doorenbosch (2013), to demonstrate heath management of the barrow landscape between $\approx 3000$ and $\approx 200 \mathrm{BC}$. Heath management after AD 500 caused two changes in the geomorphology of the landscape. Firstly plaggic horizons developed and the surface of arable fields raised; secondly severe heath degradation resulted in sand erosion and re-sedimentation. We used the Bedafse Bergen case study (van Mourik et al., 2012a) to demonstrate the impact of heath management on soils and landforms between AD 500 and 1900.

\subsection{Pollen analysis}

Pollen records of paleosols in barrow landscapes, buried podzols, and Anthrosols provide paleoecological information on plant species present on site and in the region during the formation of the barrows, drift sand deposits, and plaggic horizons. Previous research has shown that pollen grains that infiltrated soils and were incorporated into plaggic deposits are well preserved in the anaerobic and acidic microenvironment of excremental aggregates (van Mourik, 1999, 2001).

Samples for pollen extraction were collected in $10 \mathrm{~mL}$ tubes in profile pits. Pollen extractions were carried out using $10 \%$ potassium hydroxide $(\mathrm{KOH}), 10 \%$ hydrochloric acid $(\mathrm{HCl})$, bromoform-ethanol (specific gravity $=2.0$ ), and acetolysis (Moore et al., 1991, p. 50). For the identification of pollen grains, the pollen keys of Moore et al. (1991, p. 83$166)$ and Beug (2004) were applied. The pollen scores of the barrow records are based on a tree pollen sum minus Betula (in the curve of total AP (arboreal pollen), five Betula are included). The barrow pollen data used in this paper have been previously published in Doorenbosch (2013) and will be summarized in this paper with a focus on heath and heath management. Pollen scores of the archives of the Bedafse Bergen were based on a total pollen sum of arboreal and non-arboreal plant species. For the estimation of the pollen concentrations from the various soil horizons of the Rakt profile, the exotic marker grain method was applied (Moore et al., 1991, p. 53). Pollen data of the Rakt profile have been published in van Mourik et al. (2012a); the Bedafse Bergen pollen diagram has not been published before.

\section{Results}

\subsection{The Renkum stream valley}

In a stream valley near Renkum (for the location see Fig. 2) an alignment of barrows is situated with a length of at least $4.5 \mathrm{~km}$. Several barrows of this alignment, archeologically dated to the late Neolithic $\mathrm{A}(\approx 2900-2500 \mathrm{BC})$ and the late Neolithic B period $(\approx 2500-2000 \mathrm{BC})$, have been excavated and sampled for pollen. Pollen samples were taken from the old surfaces underneath the barrows and/or from the sods the barrows were built of. Palynological analyses were performed by Casparie and Groenman-van Waateringe (1980, p. 24-36), with the exception of Bennekom 1. Bennekom 1 was published by van Giffen (1954). Doorenbosch (2013) reinterpreted and published the data retrieved by the abovementioned researchers in her $\mathrm{PhD}$ thesis.

Figure 4 shows the pollen spectra from the barrows of the alignment in the Renkum stream valley. In the Neolithic A period Ericales pollen form a considerable part of the pollen spectra. Heath pollen tends to spread mostly within a few meters from the place where the heath is growing and pollen is produced (de Kort, 2002). This implies that the considerable percentage of heath pollen indicates that all investigated bar- 


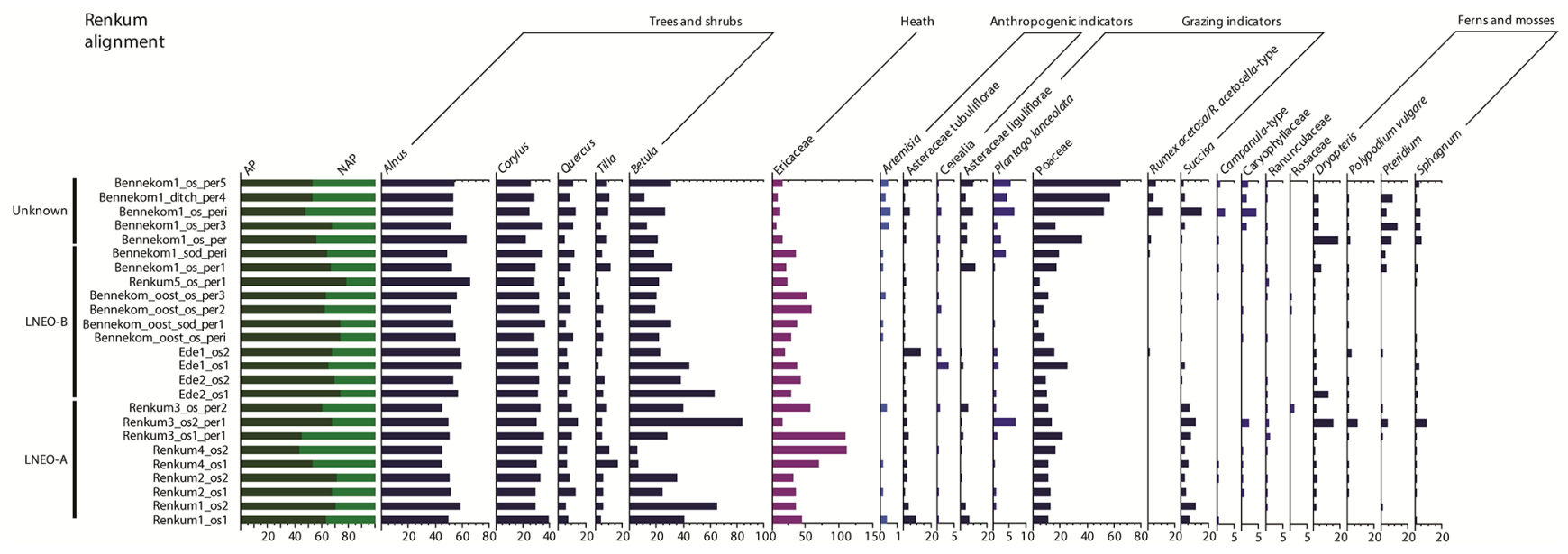

Figure 4. Pollen spectra from the samples taken from the barrows of the Renkum alignment.

rows in the area were constructed in an open space with vegetation where heath was an important component. In addition to heath, grasses also formed part of the vegetation in the open places. Arboreal pollen percentages fluctuate between barrows from around 45 to around $75 \%$, indicating varying sizes of the open spaces the barrows were situated in. Based on research that was performed in recent heath areas with varying distances to the forest, such arboreal pollen percentages indicate that the open spaces had an average distance to the forest of 30-250 m (Doorenbosch, 2013, chap. 7). The forest consisted mainly of oak (Quercus) and hazel (Corylus), while alder carr (Alnus) was present in the wetter parts of the landscape. The barrows that date to the late Neolithic B period show a similar vegetation composition. Apparently these barrows were also built in open spaces, of which heath and grasses were the main components. The size of the open spaces seems to be smaller than during the Neolithic A period. Arboreal percentages are lower, indicating an ADF (average distance to the forest) of approximately $50 \mathrm{~m}$ (Doorenbosch 2013, chap. 7).

Besides the barrows that have been palynologically investigated in this area, palynological data from many other barrows in the Pleistocene cover sand areas in the Netherlands are known (see Sects. 3.2, 3.3; see also Doorenbosch, 2013). These data show that these barrows were also built in heaths. Only a fraction of the barrows have been preserved to present (Bourgeois, 2013, p. 40); originally the number of barrows was much higher in the Netherlands, and only a part of these preserved barrows have been palynologically analyzed. Considering that all investigated barrows were built in heath vegetation, it is probable that the non-investigated barrows in these areas were also built in open spaces where heath vegetation was dominant. The barrows of Renkum were built in an alignment, and the distance between the barrows is mostly less than a few hundred meters. Since the average distance to the forest of the open spaces varies from 50 to $300 \mathrm{~m}$, it is likely that the open spaces were connected to each other, forming relatively small but long-stretched heathland areas with a length that could add up to several kilometres (Fig. 5).

\subsection{Vaassen-Niersen}

A second example is given in Fig. 6, showing the results for several barrows that are situated in the northeastern part of the Veluwe (for the location see Fig. 2). In this area several barrow alignments and solitary barrows are present. Palynological data are available for five burrows in this area. Data were obtained from the old surfaces underneath the barrows, from sods from several periods in which the barrows were constructed (in several cases barrows were constructed in multiple phases: the barrow was reused for secondary burials and new sods were added to the original barrow to cover these burials), as well as from ditches associated with the barrows. These barrows were dated from the late Neolithic A to the Middle Bronze Age period $(\approx 1800-1100 \mathrm{BC}$ ) (Casparie and Groenman-van Waateringe, 1980; Doorenbosch, 2013). Two of these barrows form part of a barrow alignment.

The pollen spectra show that the barrows in this area, like the barrows in the Renkum stream valley, were built in open places with heath vegetation, surrounded by oak forest and alder carr in the lower parts of the area. The open spaces were probably larger than in the Renkum stream valley, with an ADF of around $100 \mathrm{~m}$ for the barrows of Vaassen and an ADF of 100-200 $\mathrm{m}$ for the barrows of Niersen.

The vegetation of the open space seems stable, since the barrow spectra from all represented periods show similar vegetation patterns: an open place with species-poor grassy heathland surrounded by oak forest with an alder carr nearby. Figure 7 shows the visual impact on the landscape in the area of Vaassen-Niersen, assuming all barrows were built in heath. 


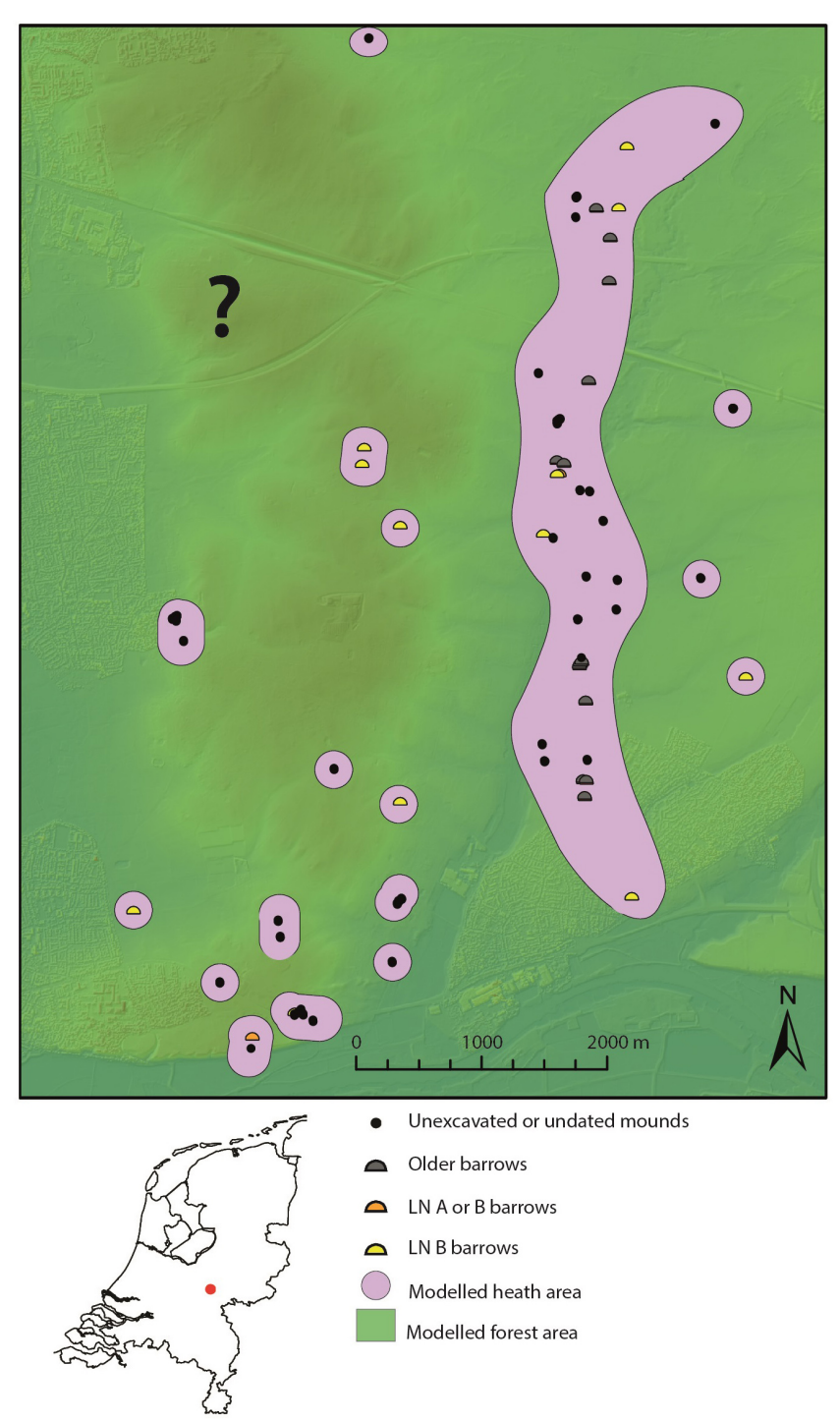

Figure 5. Barrow alignments of Renkum, situated in a (hypothetical) long-stretched heath area surrounded by forest. The vegetation reconstruction is based on palynological data from barrows. An exact reconstruction of the forest area is therefore not possible (indicated by the question mark), since barrows are not present in those areas. The figure is based on the digital elevation model of the AHN ( ${ }^{\circledR}$ www.ahn.nl). Figure after Doorenbosch (2013, Fig. 13.2c).

\subsection{Echoput}

A third example concerns the twin barrows of the Echoput (site indicated in Fig. 2), which date to the middle or earlier late Iron Age (Bourgeois and Fontijn, 2011, p. 87; Doorenbosch, 2013; van der Linde and Fontijn, 2011, p. 62). These barrows were excavated and sampled for pollen analyses by the Faculty of Archaeology of the University of Leiden (Doorenbosch, 2011). The pollen analyses were performed by the first author of this article as part of her $\mathrm{PhD}$ research (Doorenbosch, 2013). From both burial mounds sam- ples were taken from the old surface and several sods. In addition, the soil profiles underneath both barrows were sampled. Results are shown in Figs. 8, 9, and 10.

The pollen spectra from the old surfaces and sods consist mainly of herbaceous pollen, dominated by heather ( $\mathrm{Cal}$ luna vulgaris) and less, but still in considerable amounts, by grasses. This indicates that the Echoput barrows were both built in an open space dominated by heather. The open spaces were surrounded by forest vegetation, namely oak, hazel, and alder. The open heath areas were probably much larger than at the older barrows described in the first two examples. At the Echoput the ADF was around $200-300 \mathrm{~m}$. The open spaces had not been recently created when the barrows were built. The heath vegetation had already had time to establish and to develop, and the open place must have existed at least some years before the barrows were built. This is confirmed by the pollen diagrams shown in Figs. 9 and 10. These diagrams show the vegetation development from a certain period prior to the barrow building. Although the soil profiles have not been dated, it is clear that heath was already present some time before the barrows were constructed. The diagrams show a decrease of the surrounding forest and an increase of the heath vegetation, and at the time the burial mounds were built vegetation was dominated by heather.

\subsection{Bedafse Bergen}

The "Bedafse Bergen" is a biogenic land dune ridge west of Rakt, a historical complex of a hamlet and arable fields, surrounded by coppice. West of the hamlet, cattle heathland was present. A plaggic Anthrosol developed on the arable fields (Fig. 11, phase A). After AD 1000 the heaths in this region were threatened by sand drifting due to severe forest degradation. The degradation was caused by complete deforestation during the 11th-13th century (Vera, 2011; van Mourik et al., 2012a, b). This deforestation triggered the first regional extension of (older) sand drifting; aeolian eroded sand was transported by the southwesterly winds from the heaths to Rakt. The coppice hedge around the hamlet served as a protecting screen and initiated the building of a ridge of inland dunes, the Bedafse Bergen (Fig. 11, phase B). The introduction of the deep, stable economy in the 18th century (Vera, 2011) initiated the second extension of (younger) sand drifting (Fig. 11, phase C). At the east side of the ridge, the western edge of the plaggic Anthrosol was buried by (younger) drift sand; at the west side of the ridge we could excavate the podzol in cover sand, buried by older drift sand. Both profiles were sampled for pollen analysis and OSL dating (Tables 1,2). The Ah of the buried podzol in the Bedafse Bergen profile was also sampled for radiocarbon $\left({ }^{14} \mathrm{C}\right)$ dating (Table 2). The OSL datings have been performed at the Netherlands Centre for Luminescence (NCL, Wageningen University), and the radiocarbon dating (accelerator-mass-spectrometer) at the Centre for Isotope Research (CIO, Groningen University); the methodology of 


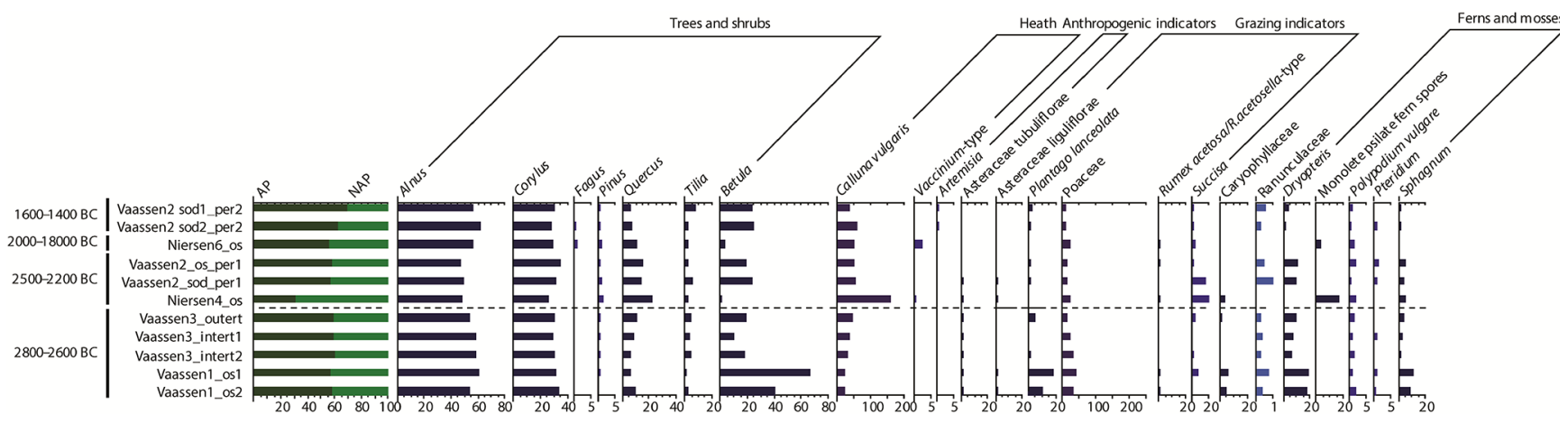

Figure 6. Pollen spectra from samples taken from the barrows at Vaassen, the barrows at Niersen barrows, and the Celtic field at Vaassen.

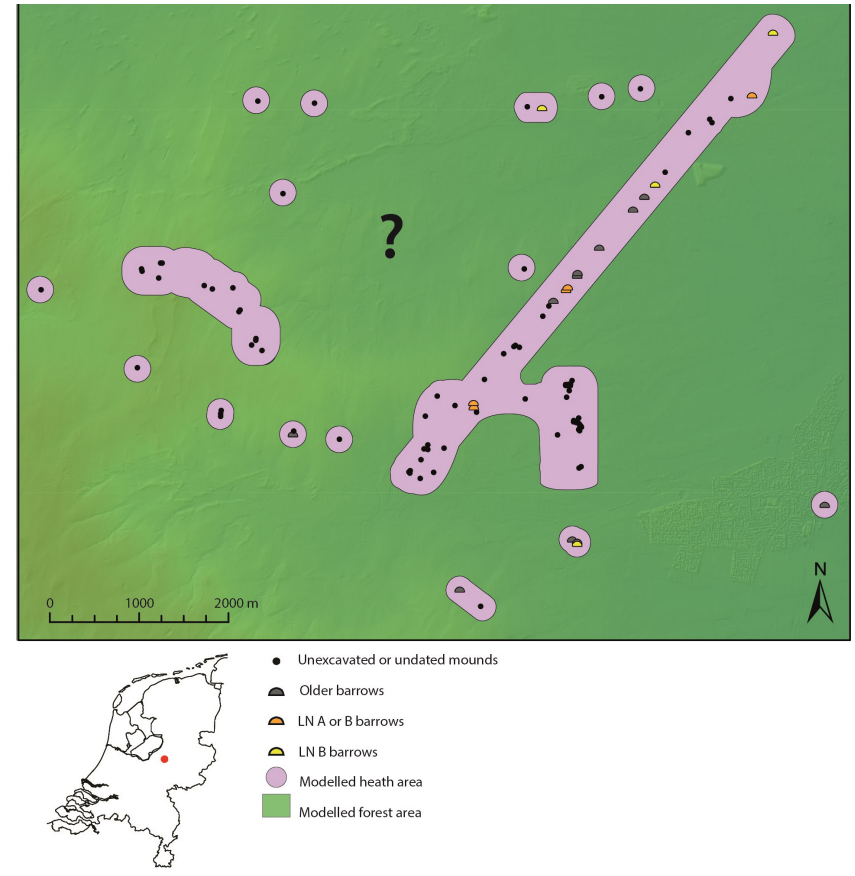

Figure 7. Barrow alignments of Vaassen-Niersen, situated in a (hypothetical) long-stretched heath area surrounded by forest. The vegetation reconstruction is based on palynological data from barrows. An exact reconstruction of the forest area is therefore not possible (indicated by the question mark), since barrows are not present in those areas. The figure is based on the digital elevation model of the AHN ( ${ }^{\circledR}$ www.ahn.nl). Figure after Doorenbosch (2013, Fig. 13.1c).

the dating techniques has been described in van Mourik et al. (2012a). The development of the landscape around the Bedafse Bergen is presented in Fig. 11, and the sampled profiles in Fig. 12.

The pollen diagram of Rakt is shown in Fig. 13, and the pollen diagram of the Bedafse Bergen in Fig. 14.

During the transformation of heaths into new arable land and forests in the 20th century, the majority of the soil archives were destroyed. For this reason, the soil archives of the Bedafse Bergen have a high scientific value. The position
Table 1. OSL datings of the Rakt profile (Fig. 10, left).

\begin{tabular}{lcc}
\hline Soil horizon & OSL ring & OSL ages \\
\hline C top & L7 & AD 1812 \pm 9 \\
C bottom & L6 & AD 1808 \pm 8 \\
2Aan1 bottom & L5 & AD 1781 \pm 9 \\
2Aan2 top & L4 & AD 1685 \pm 14 \\
2Aan2 middle & L3 & AD 1593 \pm 17 \\
2Aan2 bottom & L2 & AD 1417 \pm 37 \\
3Ap & L1 & AD 0069 \pm 89 \\
\hline
\end{tabular}

Table 2. Absolute dating of the Bedafse Bergen profile (Fig. 10, right).

\begin{tabular}{lccc}
\hline Horizon & $\begin{array}{c}\text { OSL ring/ } \\
{ }^{14} \text { C box }\end{array}$ & OSL dating & $\begin{array}{c}{ }^{14} \mathrm{C} \text { humic } \\
\text { acids }\end{array}$ \\
\hline $2 \mathrm{C} 2-3$ & L3 & AD 1473 \pm 40 & - \\
$2 \mathrm{C} 4-5$ & L1 & AD 1425 \pm 40 & - \\
2 C6-7 & L1 & AD 1365 \pm 40 & - \\
3 Ah & RC & - & AD 725 \pm 39 \\
\hline
\end{tabular}

of the sampled profile is indicated in Fig. 11c. The oldest formation is cover sand. The post-sedimentary infiltrated pollen spectra of the 3Ap in cover sand demonstrate that arable land was created on Calluna heath. Conventional radiocarbon dates of the humin and humic acid fractions of a similar profile on the nearby Maashorst indicate a start of sedentary agriculture around $1000 \mathrm{BC}$ (van Mourik et al., 2012a). The OSL dating (L1) of the 3Ap reflects ploughing of the agricultural soil until around AD 100 (ploughing resulted in bleaching of quartz grains, originally part of the cover sand deposit). Until $\approx \mathrm{AD} 1600$ the plaggic deposition rate was relatively low (2Aan2). After AD 1600 the OSL datings point to an acceleration of the plaggic deposition (2Aan1), related to an increasing content of mineral grains of the plaggic manure. It is known that in the course of the 18th century farmers used, in addition to straw, Calluna heath sods as stable filling (van Mourik et al., 2016). The difference in acceler- 


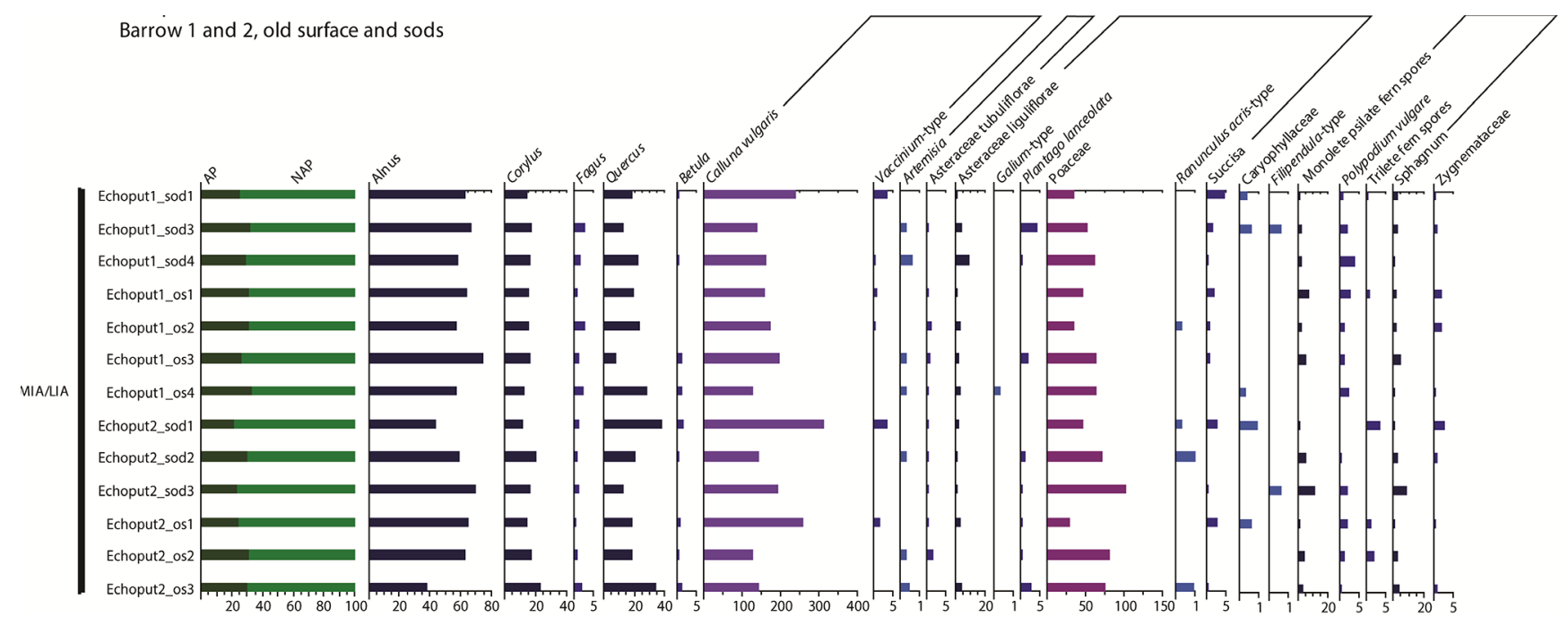

Figure 8. Pollen spectra from the sod and old surface samples taken from Echoput barrow 1 and 2.

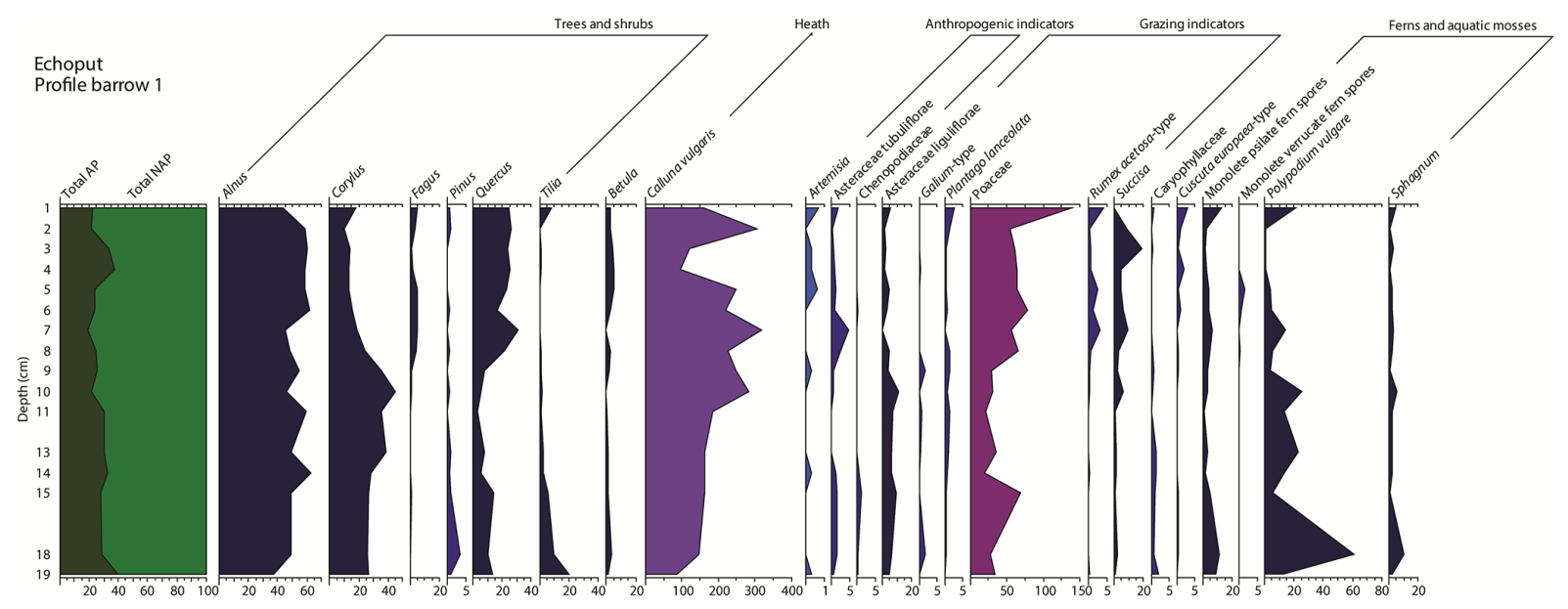

Figure 9. Pollen diagrams derived from the series of samples taken from underneath Echoput barrow 1.

ation rate is also reflected by the pollen density curve. The plaggic Anthrosol was buried by (younger) drift sand around AD 1800.

The buried podzols of the Bedafse Bergen and Rakt profiles developed originally at the same stratigraphic level in cover sand. The position of the sampled profiles is indicated in Fig. 11c. The Bedafse Bergen podzol is buried below $12 \mathrm{~m}$ high dune sand deposits. Only the basic layers of the drift sands and the top horizons of the podzol have been sampled for pollen analysis and dating of the basis of the older drift sand deposits. The pollen spectra of the horizons of the buried podzol contain high percentages of Ericaceae, pointing to the presence of heath. The relatively high percentages of Quercus and Corylus refer to deciduous forest in the surroundings. The pollen spectra of the drift sand layers show lower percentages of Ericaceae and higher percentages of Poaceae, indicating heath degradation. The decrease of Quer- cus refers to deforestation. The oldest drift sand layers were deposited between $\approx \mathrm{AD} 1300$ and $\approx \mathrm{AD} 1500$. This correlates to a period of deforestation, as has been documented in historical documents (Vera, 2011). The radiocarbon age of the humic acids, extracted from the $3 \mathrm{Ah}$, is $\approx \mathrm{AD} 725$. It is known that radiocarbon ages of humic horizons of paleosols overestimate the real ages (van Mourik et al., 2010).

\section{Discussion}

\subsection{The barrow heath landscape and heath management}

Based on the examples given above and many other palynologically investigated barrows (Doorenbosch, 2013), it can be concluded that barrows were built in open spaces that varied in size from small, with an average distance to the forest $(\mathrm{ADF})$ of $\approx 50-100 \mathrm{~m}$ for the oldest barrows, to rather large 


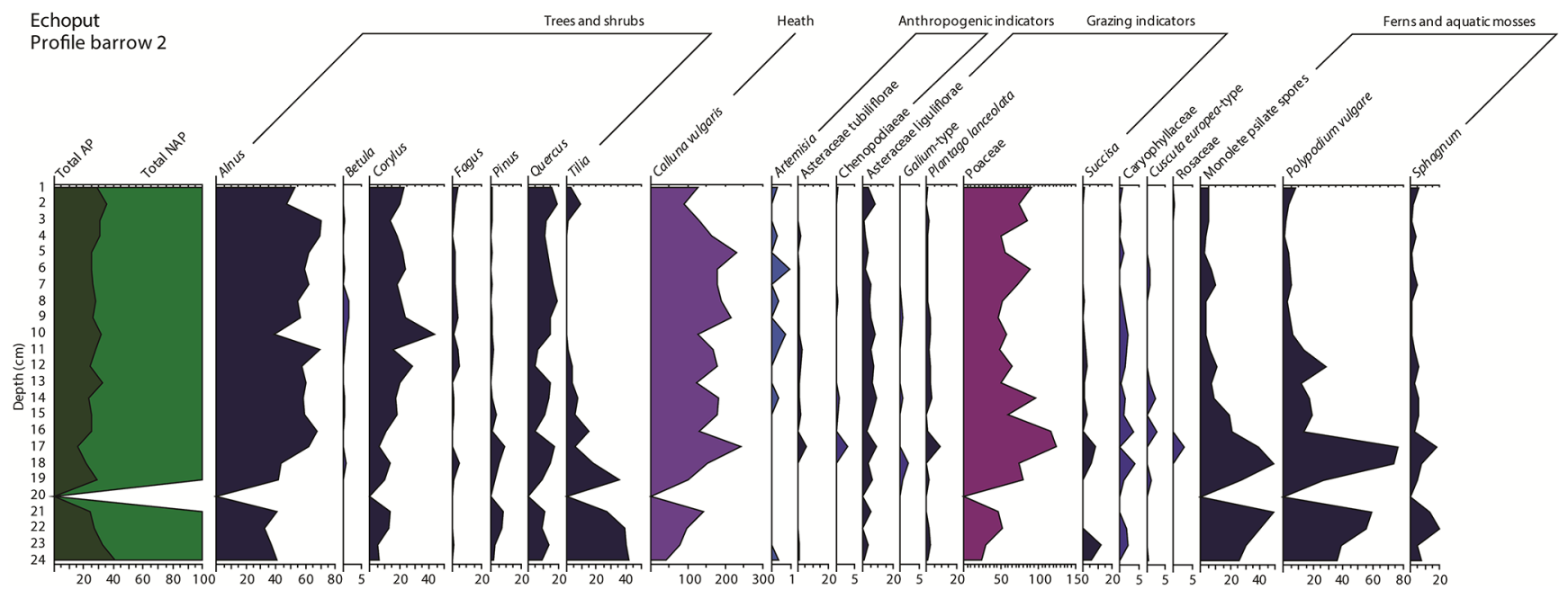

Figure 10. Pollen diagrams derived from the series of samples taken from underneath Echoput barrow 2.
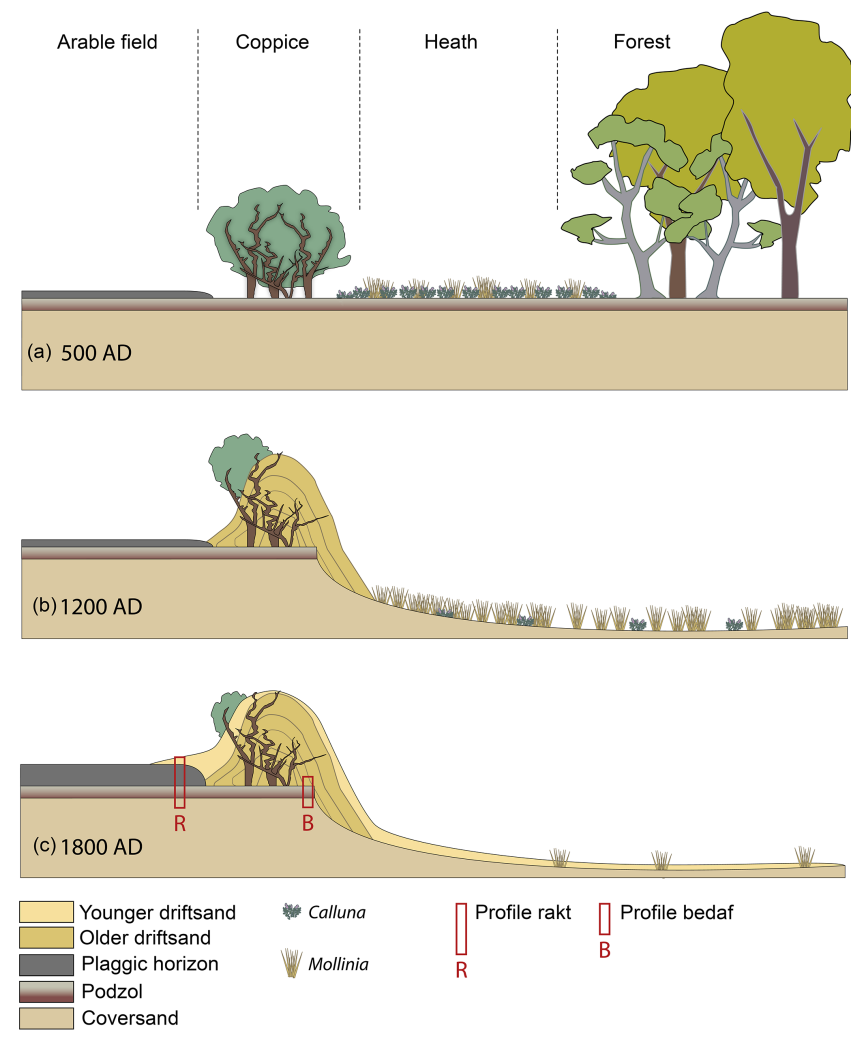

Figure 11. Sequence of development phases of the Bedafse Bergen and its soil archives.

$(\mathrm{ADF} \approx 300 \mathrm{~m})$ for the younger Iron Age barrows. In several cases these open spaces were connected to each other, forming long-stretched heath areas. In the case of the Echoput barrows it was shown that the open space with heath vegetation was already present some time before the barrows were built. For the other investigated barrows such a vegeta-

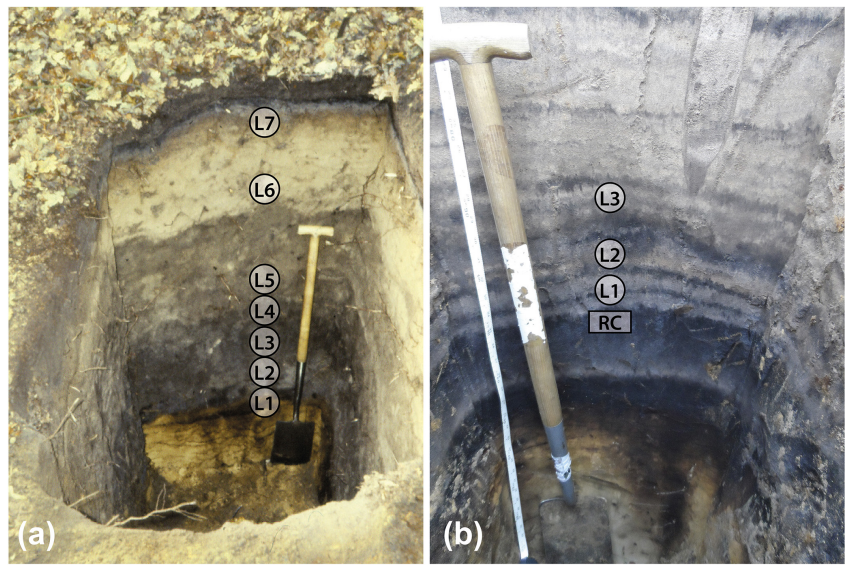

Figure 12. The soil archives of the Bedafse Bergen (left: Rakt; right: Bedafse Bergen). The sample locations for OSL are indicated with rings, and for ${ }^{14} \mathrm{C}$ with a cube.

tion history has not been reconstructed. However, in all cases heath and herb vegetation had already developed at the barrow places. This suggests that these heath areas were already present some time before the barrows were built in all cases. This is also confirmed by for example the studies of Sevink et al. (2013) on early pre-barrow paleosols in the Laarderwasmeer area and by van Mourik et al. (2012a) at the Schaijkse Heide. In the pollen diagrams from these soils heath was already continuously present around $5000 \mathrm{BC}$.

The open spaces covered with heath vegetation must have been kept open until the barrows were built, and in most cases they were kept open long after the barrows had been built. To maintain the heath, the landscape must have been managed. When heath is not managed, other plant species will replace the heath vegetation. Management activities like grazing, sod cutting, and burning could have been carried out to maintain 


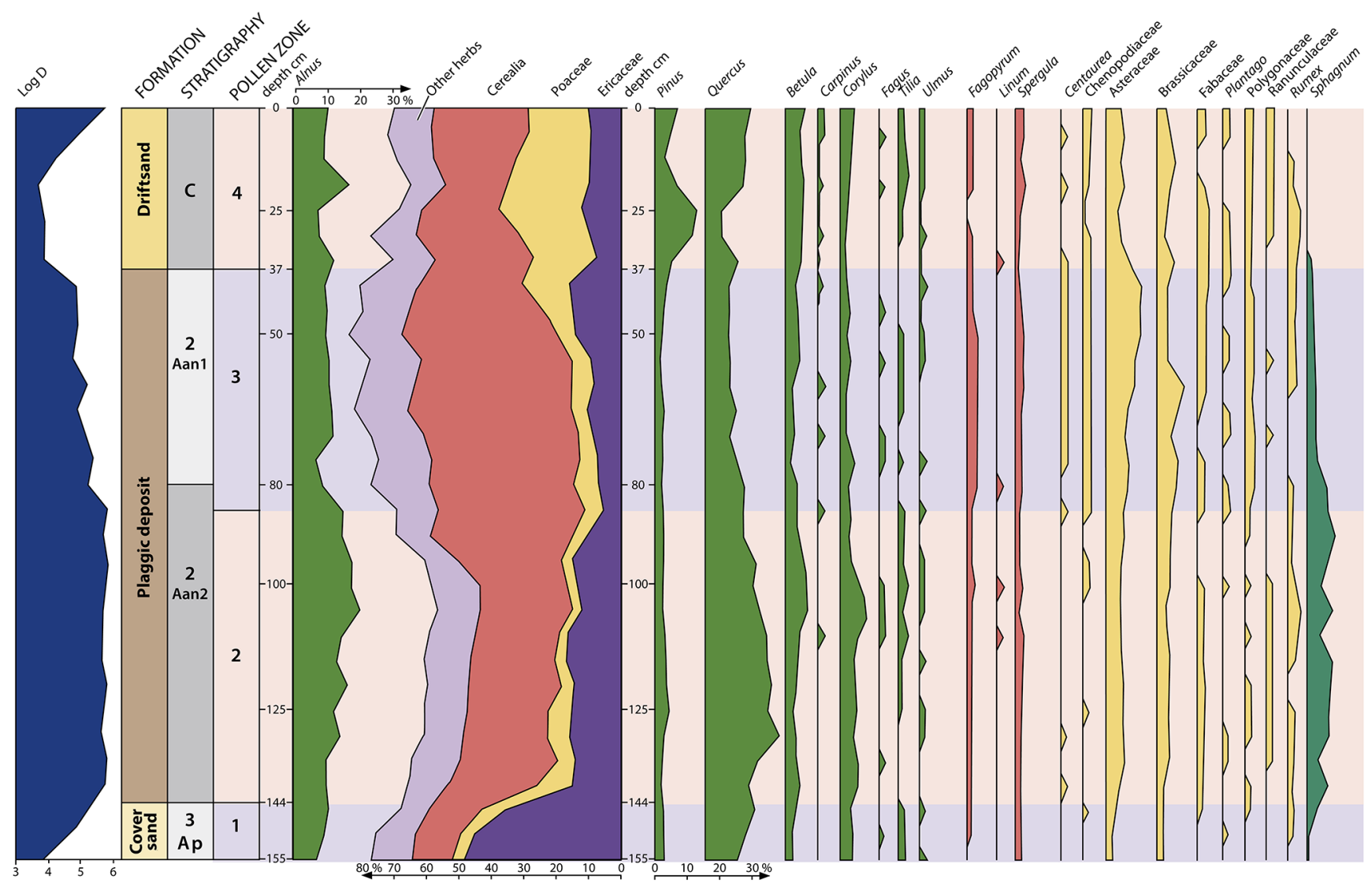

POLLEN DIAGRAM RAKT

Figure 13. Pollen diagram of Rakt.

the heath vegetation. Although for the earliest heathland areas (e.g. the Laarderwasmeer area) no clear indications for heath management, such as grazing, have been found, it is assumed that the heath vegetation was maintained by anthropogenic influences.

For the late Neolithic, when the first barrows were built, indications for heath management are clearer. Sod cutting must have taken place for the purpose of the barrow building, but the amount of sods needed to build a barrow is not sufficient to explain the size of the heath areas. Burning might have been part of the heath management activities. Indications for burning have only been found in a few cases by the recording of charcoal that was probably not just related to the burial itself. Indications for large-scale burning of the heath areas have not been found, however. Grazing indicators such as grasses (Poaceae), Plantago lanceolata, Asteraceae Liguliflorae, Succisa, and Galium could be an indication that the heathlands have been grazed (Hjelle, 1999). Such grazing indicators are present in all the presented pollen spectra (Figs. 4, 6, 8, 9, 10), making it likely that grazing was involved in the heath management activities of prehistoric man.

Archeozoological evidence from several excavations suggests that prehistoric farming communities kept mainly sheep and cattle (Brinkkemper and van Wijngaarden-Bakker, 2005, p. 493). In present times both sheep and cows are used to maintain heathland areas by grazing. Young $\mathrm{Cal}$ luna heath is favored by sheep, together with grass and herb vegetation. Sheep are not very fond of older Calluna plants (Elbersen et al., 2003). Cattle prefer mainly grasses, although some landraces also eat young Calluna plants (Lake et al., 2001, p. 31). To prevent grasses and other plant species from getting dominant in heathland areas, one sheep per hectare and/or one head per 5-6 ha is required (Elbersen et al., 2003; Siebel and Piek, 2001; Verbeek et al., 2006). The number of livestock belonging to late Neolithic farming communities has not been estimated, but for the Middle Bronze Age B it has been suggested that up to 30 livestock animals could be kept per household (Fokkens, 2005, p. 427). For the Iron Age, estimated numbers are lower (Brinkkemper and van Wijngaarden-Bakker, 2005). Assuming the amount of barrows was numerous, with each barrow lying in a heath area of approximately 3 ha (based on an ADF of $100 \mathrm{~m}$ ), several households, forming heath communities, must have worked together to maintain the barrow heathland. Whether prehistoric man carried out the heath management activities ascribed above, especially grazing, with the aim of manag- 


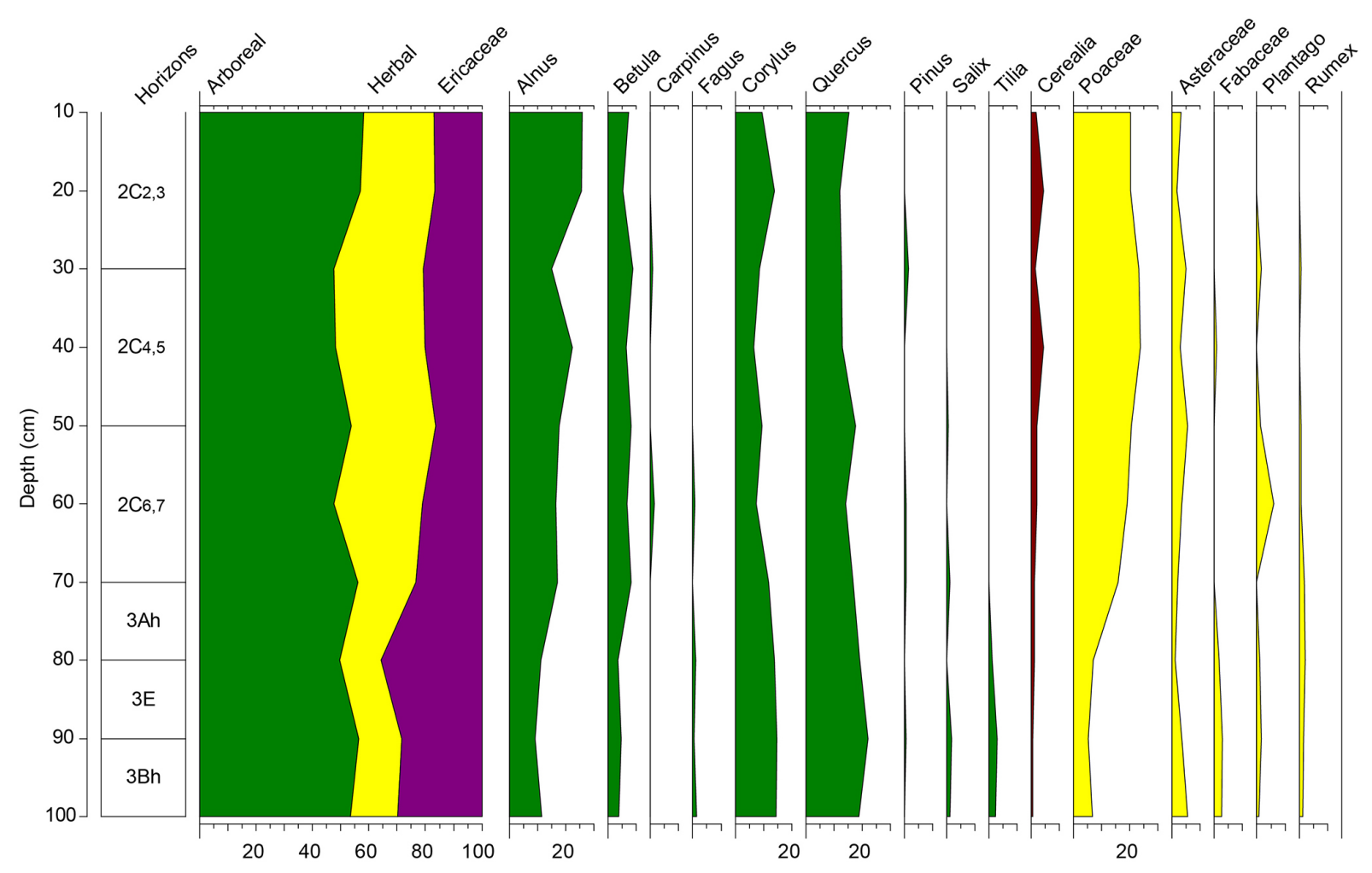

Figure 14. Pollen diagram of the Bedafse Bergen.

ing the heath is not known for certain. They might have been practiced as part of their daily (agricultural) activities, while managing the heath was incidental. However, they must have realized what impact their grazing activities had on the heathland. Since overgrazing leads to the destruction of the heathland, causing possible sand drifting events, and since with grazing pressure too low in the areas with heath vegetation the heath plants will be taken over by other species, prehistoric man must have adjusted grazing activities in such a manner that the heath was preserved for thousands of years. For certain, heath was very important for prehistoric man during the period in which they built barrows. They might have considered the heaths as ancestral, since they did not only serve as burial placed for ancestors, but they also had been used and managed by these ancestors prior to the barrow building. As such the heaths formed part of the economic zone of the people living in the area. The ancestral heaths were very stable elements in the landscape and were kept in existence for thousands of years, forming the most important factor in structuring the barrow landscape.

\subsection{Heath in the Roman period}

Unfortunately, not much is known about heath and the maintenance of heath during the Roman period. The practice of barrow building was no longer continued and no soil records have been investigated that could give information on the use of heathland in the period thereafter. Some studies have been conducted, however, suggesting that heathland areas continuously existed throughout the Roman period, indicating that some form of heath management must have taken place during that time, for example at the Echoput (see Sect. 3.3). At the Echoput heath was present at and prior to the period in which the barrows were built (the late Iron Age). This heath area must have been managed for some time in order to have been maintained. At the same site several post holes have been discovered close to the barrows. The infill of these post holes, which probably date to the late Medieval Period, has been analyzed for pollen as well (Doorenbosch 2013, chap. 8.1). It was shown that at the time the posts were placed the heath had expanded compared to when the barrows were built. It cannot be said with certainty that the heath was present and maintained in the period in between the barrow building and the post placing, but it is likely that this is the case. The presence of heath during the Roman period was also shown in pollen diagrams from several paleosols, for example Venloop (Maashorst, North Brabant; van Mourik et al., 2012a) and Defensiedijk (Weert, central Limburg; van Mourik et al., 2010). In addition, the presence of heath during the Roman period is mentioned in several other studies (Bakels, 2014; Kooijstra, 2008; Kooijstra and Groot, 2015). With the continuous presence of heath vegetation it is most probable that the local population continued with extensive grazing management on the heaths until the early 
Middle Ages. In Twente and Drenthe (eastern Netherlands) the sustainable management of the common heaths was controlled by the so-called Marke administrative system (Spek, 2004); in the Campina (southern Netherlands) the stability of the common heaths was the common denominator of sustainable agricultural production of the smallholders and the elites (de Keyzer, 2013). Small-scale events such as storms and fires could destabilize the ecosystems for a relatively short time, but commercial interventions caused more permanent destabilization and sand drifting: the iron industry from the Iron Age till the 7th century (Beukenkamp and Sevink, 2005), the deforestations from the 11th-13th century, and the introduction of the deep, stable economy in the course of the 18th century (Vera, 2011).

\subsection{Heath management since AD 500: plaggic agriculture, sand drifting, reclamation, and restoration}

In the early Middle Ages people learned to produce manure by using organic materials such as the ectorganic horizon of deciduous forests and grass sods from the brook valleys as stable fillings (van Mourik et al., 2016). Serious degradation of heaths during this time is not recorded in the soil archives. Heath management was most probably restricted to burning and mowing of older Calluna shrubs (Burny, 1999).

During the 11th-13th century, landowners cut the last forests, because the prices of wood were going up (Vera, 2011). These deforestations resulted in regional extension of sand drifting (van Mourik et al., 2012a, b). To acquire fuel, farmers dug sods of the ectorganic horizon of the moist heaths (Burny, 1999), but after the removal of the ectorganic sods, the moist heaths will recover in 2-4 years, and sand drifting was not an issue. From archived documents it is known that the farmers protected the dry heaths carefully against sand drifting (Vera, 2011). But in the course of the 18 th century the combination of population growth and the increase in food demand resulted in the extension of arable fields and the increase of the production of stable manure. The lack of stable fillings was compensated by the use of humic sods from the dry heaths (Vera, 2011; Burny, 1999). Mowing and burning were sustainable management rules, but sod digging caused degradation and initiated the next wave of sand drifting (van Mourik et al., 2012a, b).

At the end of the 19th century, the plaggic agriculture came to an end. Due to the combination of the falling prices of wool and the introduction of chemical fertilizers and urban compost, the heaths lost their economic value and the government started with the reclamation of the heaths into new arable fields. After the introduction of hybrid maize in AD 1950, these fields became the base of the bio-industry (chicken, beef, and pork). The heathlands that were damaged by sand drifting were turned into forests, mainly Scotch pine plantations. Figure 2 shows how the heath surface diminished from $\approx 600 \mathrm{kha}$ in 1850 to $\approx 30 \mathrm{kha}$ in 1990 . In 1980 the government started the development of the national ecological master structure to improve the biodiversity on a national and regional scale. The program Natura 2000 included the preservation of the remaining heaths and restoration of lost heaths. As a result, the heath area had increased from 30 to $35 \mathrm{kha}$ in 2008. Most of these heaths are now parts of protected nature reserves, in which also the (last) valuable soil archives such as barrows, buried podzols, and plaggic horizons are protected as elements of the geological and cultural heritage.

Due to the presently increased nitrogen concentrations in rain and groundwater, heaths cannot survive without management measures to prevent an accelerated succession to brushwood and forest. Applied measures are, like in the 19th century, intensive grazing, mowing, burning and sod digging (Smits and Noordijk, 2013).

\section{Conclusions}

The invasion of heaths into the cover sand landscape of the Netherlands is associated with forest degradation - first on a small scale in open places in the original forest, which existed due to natural causes, followed by larger-scale anthropogenic deforestations.

- People created and maintained the barrow landscape on ancestral heaths from the late Neolithic until the late Iron Age.

- For these people, heath was not only economically but also culturally valuable.

- During and after the Roman period, people continued with heath management, mainly by cattle grazing; the heaths maintained their economic but lost their cultural value.

- Introduction of the plaggic agriculture system around AD 500 resulted in further soil acidification of the heaths and the development of plaggic horizons on arable fields.

- Deforestations during the 11th-13th century caused extension of sand drifting, and the introduction of the deep, stable economy in the 18th century resulted in extensions of the drift sand landscape and heath degradation.

- At the end of the 19th century the heaths lost their economical functions and were transformed into modern production fields.

- The loss of the heath area was accompanied by the loss of soil archives.

- Preservation of the remaining soil archives is crucial for the geological heritage and future research. 
Acknowledgements. The study of the barrows resulted from the project "Ancestral Mounds at the Leiden University, funded by NWO, Netherlands Organization for Scientific Research". We are grateful to Jakob Wallinga (NCL, Wageningen University) for the performance of the OSL datings of the Rakt and Bedafse Bergen profiles. For the ${ }^{14} \mathrm{C}$ datings of the barrows of the Echoput and the buried podzol of the Bedafse Bergen profile we thank Hans van der Plicht (CIO, University of Groningen). We thank Jan van Arkel (IBED, University of Amsterdam) for the production of some of the digital illustrations.

We thank the reviewers Bas van Geel, Jan Sevink, Martina Glocke, and Sjoerd Kluiving for their valuable advice on how to improve the quality of this paper.

Edited by: S. Kluiving

\section{References}

Bakels, C. C.: Van berken tot boekweit: de vegetatie van de Maaskant, in: De archeologische schatkamer Maaskant, bewoning van het Noordoost-Brabantse rivierengebied tussen $3000 \mathrm{v}$. en 1500 n.Chr., edited by: Jansen, R., Sidestone Press, Leiden, 51-63, 2014.

Beug, H. J.: Leitfaden der Pollenbestimmung für Mitteleuropa und angrenzende Gebiete, Verlag Dr. Friedrich Pfeil, München, 2004.

Beukenkamp, P. C. and Sevink, J.: Natuur en landschap, in: De Hoge Veluwe, natuur en kunst, 38-97, Stichting De Hoge Veluwe/Uitgeverij Waanders, Zwolle, 2005.

Bloemers, J. H. F.: Het Urnenveld uit de Late Bronstijd en Vroegere IJzertijd op de Boshoverheide bij Weert, KNAG/UvA, Amsterdam, Nederlandse Geografische Studies, 74, 59-137, 1988.

Bourgeois, Q. P. J.: Monuments on the Horizon. The formation of the barrow landscape throughout the 3rd and 2nd millennium BC, Dissertation, University of Leiden, Leiden, 2013.

Bourgeois, Q. P. J. and Fontijn, D. R.: Antiquarian leftovers Mound 2, chap. 3, in: Iron Age Echoes: Prehistoric land management and the creation of a funerary landscape - the "twin barrows" at the Echoput in Apeldoorn, edited by: Fontijn, D. R., Bourgeois, Q. P. J., and Louwen, A. J., Sidestone Press, Leiden, 65-90, 2011.

Brinkkemper, O. and van Wijngaarden-Bakker, L.: All-round farming. Food production in the Bronze Age and the Iron Age, in: The prehisotry of the Netherlands, edited by: Louwe Kooijmans, L. P., van den Broeke, P. W., Fokkens, H., and van Gijn, A. L., Amsterdam University Press, Amsterdam, 491-512, 2005.

Burny, J.: Bijdrage tot de historische ecologie van de Limburgse Kempen (1910-1950), Natuurhistorisch Genootschap in Limburg XLII(1), Maastricht, 1999.

Casparie, W. A. and Groenman-van Waateringe, W.: Palynological analysis of Dutch barrows, Palaeohistoria, 22, 7-65, 1980.

Castel, I. I. Y.: Late Holocene eolian drift sands in Drenthe (The Netherlands), Dissertation, University Utrecht, 1991.

De Keyzer, M.: The common denominator; the survival of the commons in the late mediaval campina area, Universiteit Antwerpen, Antwerpen, Belgium, 2014.

De Kort, J.-W.: Schapen op de heide. Een vegetatiereconstructie van de omgeving van het vorstengraf van Oss in de Vroege IJzertijd, in: 2000 jaar bewoningsdynamiek. Brons- en ijzertijdbewoning in het Maas-Demer-Scheldegebied, edited by: Fokkens, H. and Jansen, R., Leiden University, Leiden, 341-353, 2002.

Doorenbosch, M.: An environmental history of the Echoput barrows, chap. 5, in: Iron Age Echoes: Prehistoric land management and the creation of a funerary landscape - the "twin barrows" at the Echoput in Apeldoorn, edited by: Fontijn, D. R., Bourgeois, Q. P. J., and Louwen, A. J., Sidestone Press, Leiden, 111-128, 2011.

Doorenbosch, M.: Ancestral Heaths. Reconstructing the barrow landscape in the central and southern Netherlands, Dissertation, University of Leiden, Leiden, 2013.

Elbersen, B. S., Kuiters, A. T., Meulenkamp, W. J. H., and Slim, P. A.: Schaapskuddes in het natuurbeheer, Alterra, Research Instituut voor de Groene Ruimte, Wageningen, 2003.

Jongman, R. H. G., Bouwma, I. M., Griffioen, A., Jones-Walters, L., and Doorn, A. M.: The Pan European Ecological Network: PEEN, Landscape Ecol., 26, 311-326, 2011.

Laban, C., Kars, H., and Heidingga, A.: IJzer uit eigen bodem, Grondboor en Hamer, 42/1, 1-11, 1988.

Fokkens, H.: Mixed farming societies: synthesis, in: Prehistory of the Netherlands, edited by: Louwe Kooijmans, L. P., van den Broeke, P. W., Fokkens, H., and van Gijn, A. L., Amsterdam University Press, Amsterdam, 463-474, 2005.

Groenman-van Waateringe, W.: Palynologisch onderzoek van het urnenveld te Weert, KNAG/UvA, Amsterdam, Nederlandse Geografische Studies, 74, 59-137, 1988.

Hjelle, K. L.: Modern pollen assemblages from mown and grazed vegetation types in western Norway, Rev. Palaeobot. Palyno., 107, 55-81, 1999.

Kooijstra, L. I.: Vegetation history and agriculture in the cover-sand area west of Breda (province of Noord-Brabant, The Netherlands), Veg. Hist. Archaeobot., 17, 113-125, 2008.

Kooijstra, L. I. and Groot, M.: The agricultural basis of the Hoogeloon villa and the wider region, in: The Roman Villa of Hoogeloon and the Archaeology of the Periphery, edited by: Roymans, N., Derks, T., and Hiddink, H., Amsterdam University Press, Amsterdam, 141-162, 2015.

Koster, E. A.: De stuifzanden van de Veluwe; een fysisch geografische studie, Dissertation, University of Amsterdam, Amsterdam, the Netherlands, 1978.

Lake, S., Bullock, J. M., and Hartley, S.: Impacts of livestock grazing on lowland heathland in the UK, NERC Centre for Ecology and Hydrology and Sussex University, Peterborough, 2001.

LNV: Handboek Natuurdoeltypen: Rapport Expertisecentrum LNV 2001/20, Wageningen, 2001.

LNV: Natura 2000 doelendocument: Rapport LNV 2006/1.1, Den Haag, 2006.

Moore, P. D., Webb, J. A., and Collinson, M. E.: Pollen analysis, Blackwell Scientific Publication, Oxford, 1991.

Riksen, M., Ketner-Oostra, R., van Turnhout, C., Nijssen, M., Goossens, D., Jungerius, P. D., and Spaan, W.: Will we lose the last active inland drift sands of Western Europe? The origin and development of the inland drift-sand ecotype in the Netherlands, Landscape Ecol., 21, 431-447, 2006.

Sevink, J., Koster, E. A., van Geel, B., and Wallinga, J.: Drift sands, lakes and soils: the multiphase Holocene history of the Laarder Wasmeren area near Hilversum, The Netherlands, Neth. J. Geosci., 92, 243-266, 2013. 
Siebel, H. and Piek, H.: Veranderde inzichten over begrazing bij natuurbeheerders, Vakblad Natuurbeheer, 4, 45-49, 2001.

Smits, J. and Noordijk, J.: Heidebeheer: Moderne Methoden in een Eeuwenoud Landschap, KNNV uitgeverij, 2013.

Spek, T.: Het Drentse esdorpenlandschap, Een historisch geografische studie, Matrijs, Utrecht, vol. 2, part VI: Plaggenbodems en Plaggenlandbouw, 725-967, 2004.

van der Linde, C. and Fontijn, D. R.: Mound 1 - A monumental Iron Age barrow, chap. 2, in: Iron Age Echoes: Prehistoric land management and the creation of a funerary landscape - the "twin barrows" at the Echoput in Apeldoorn, edited by: Fontijn, D. R., Bourgeois, Q. P. J., and Louwen, A. J., Sidestone Press, Leiden, 33-64, 2011.

van Geel, B., Coope, G. R., and van der Hammen, T.: Palaeoecology and stratigraphy of the Lateglacial type section at Usselo (The Netherlands), Rev. Palaeobot. Palyno., 60, 25-129, 1989.

van Giffen, A. E.: Een Meerperioden-heuvel, Tumulus I te Bennekom, gem. Ede, Bijdragen en Mededelingen van de Vereniging Gelre, LIV, 1-21, 1954.

van Mourik, J. M.: The use of micromorphology in soil pollen analysis. The interpretation of the pollen content of slope deposits in Galicia, Spain, Catena, 35, 239-257, 1999.

van Mourik, J. M.: Pollen and spores, preservation in ecological settings, in: Palaeobiology, edited by: Briggs, D. E. G. and Crowther, P. R., Blackwell Science, II, 315-318, 2001.

van Mourik, J. M. and Slotboom, R. T.: The expression of the tripartition of the Allerød chronozone in the lithofacies of Late Glacial polycyclic profiles in Belgium and the Netherlands, Mededelingen Rijks Geologische Dienst, 52, 441-450, 1995.

van Mourik, J. M., Nierop, K. G. J., and Vandenberghe, D. A. G.: Radiocarbon and optically stimulated luminescence dating based chronology of a polycyclic driftsand sequence at Weerterbergen (SE Netherlands), Catena, 80, 170-181, 2010.

van Mourik, J. M., Slotboom, R. T., and Wallinga, J.: Chronology of plaggic deposits; palynology, radiocarbon and optically stimulated luminescence dating of the Posteles (NE-Netherlands), Catena, 84, 54-60, 2011. van Mourik, J. M., Seijmonsbergen, A. C., Slotboom, R. T., and Wallinga, J.: The impact of human land use on soils and landforms in cultural landscapes on aeolian sandy substrates (Maashorst, SE Netherlands), Quatern. Int., 265, 74-89, 2012a.

van Mourik, J. M., Seijmonsbergen, A. C., and Jansen, B.: Geochronology of Soils and Landforms in Cultural Landscapes on Aeolian Sandy Substrates, Based on Radiocarbon and Optically Stimulated Luminescence Dating (Weert, SE-Netherlands), Radiometric Dating, 75-114, 2012b.

van Mourik, J. M., Wagner, T. V., de Boer, J. G., and Jansen, B.: The added value of biomarker analysis to the genesis of Plaggic Anthrosols; the identification of stable fillings used for the production of plaggic manure, SOIL, in press, 2016.

Vera, H.: ... Dat men het goed van den ongeboornen niet mag verkoopen, Gemene gronden in de Meierij van Den Bosch tussen hertog en hertgang 1000-2000, Uitgeverij BOXpress, Oisterwijk, Netherlands, 2011 (with English summary).

Verbeek, P. J. M., de Graaf, M., and Scherpenisse, M. C.: Verkennende studie naar de effecten van drukbegrazing met schapen in droge heide: effectgerichte maatregel tegen vermesting in droge heide, Directie Kennis, Ministerie van Landbouw, Natuur en Voedselkwaliteit, Ede, 51 pp., 2006.

Waterbolk, H. T.: De praehistorische mens en zijn milieu, Een palynologisch onderzoek naar de menselijke invloed op de plantengroei van de diluviale gronden in Nederland, University of Groningen, Netherlands, 1954.

Weeda, E. J., Westra, R., Westra, Ch., and Westra, T.: Nederlandse Oecologische Flora, deel 3, Heidefamilie, Uitgave IVN in samenwerking met VARA en VEWIN, 30-53, 1988.

Willemse, N. W. and Groenewoudt, B. J.: Resilience of Meta-Stable Landscapes? The Non-Linear Response of Late Glacial Aeolian Landforms to Prehistoric Reclamation along Dutch River Valleys, eTopoi, Journal for Ancient Studies. Special Volume 3, 1007-1037, 2012. 